\title{
EMPOWERING THE USERS IN ACADEMIC LIBRARY FOR A BETTER FUTURE
}

\author{
Dr. Priyanki Vyas \\ Ms. Daxa G. Patel
}

\begin{abstract}
The main purpose of this paper is to enlighten thebasic concept of user empowerment. The important role of the academic libraries and library professionals is to empower the students, research scholars and faculties for maximize and effective use of academic resources to enable them to develop skills \& ability for self-empowering This paper discuss about the need of user empowerment, teaching tool \& techniques, role of library professionals in user empowerment in academic library.
\end{abstract}

Keywords : User Empowerment, Academic Library, LIS Professionals

\section{Introduction:}

Academic libraries are knowledge hub and service provider of their institute or organization. They are playing an important role in widen support for the teaching-learning process, research and development and other academic activities. Now due to impact of ICT everything is moving and changing so rapidly. In ICT era librarianship, library resources, services and satisfaction of the library users are the important for any library. Library and Information Centers are in this new era is not just a collection of documents but in the words of Maurice $B$. Line, (1996) it is 'managing information resources for the people'1, here M. B. Line emphasizes on library users' satisfaction and also basically implementing Ranganathan's Second Law of librarianship. In context of this we have to empower our users to make efficiently and effective use of information. 
However, conventionally library teaching tasks were to train users on how to library resources. At the present time, libraries have to educate users in CD/DVD use, use of e-resources, retrieval of online database, Internet navigation, OPAC, access to remote information providers and even train users in the use of hardware \& software. Now a day in the academic library, librarians have, as the key duty, to instruct users on how to retrieve information. However, the library staff also faces the challenge of cultivating them how to do research. Students usually have lack of interest in reading and limited writing skills and little motivation to attend a library.

\section{What is User Empowerment:}

As per the Business Dictionary the meaning of "Empowerment is based on the idea that giving employees skills, resources, authority, opportunity, motivation, as well holding them responsible and accountable for outcomes of their actions, will contribute to their competence and satisfaction" 2 . This definition is totally relevant in LIS field that is focusing to develop skills $\&$ ability in users to self-empower.

Harvey $(2004)^{3}$ defines empowerment as the development of knowledge, skills and abilities in the learner to enable them to control and develop their own learning. "Information literacy is a means of individual empowerment within today's information society (ALA, 1998). ${ }^{4}$ The library, as an integrating part of the overall learning arena in higher education, can contribute to user empowerment through information literacy education. In this context, empowerment can be defined as 'providing users with the necessary skills to find and exploit information that they need for work, study and leisure' (Hewer, 1999). ${ }^{5}$

\section{Functions of Academic Library :}

Academic library's main function is to support their parent organization in achieving the organizational objectives. As the name suggest academic libraries are involved in providing support for research and educational activities in universities, institutions, and other academic organizations. ${ }^{6}$

As per the State of American Library Report 2012 the Rank of Functions of Academic Libraries are mentioned below: 
- The library supports and facilitates faculty teaching activities.

- The library helps undergraduates develop research and information literacy skills.

- The library provides active support that helps increase the productivity of faculty research and scholarship.

- The library pays for resources faculty members need, from academic journals to books to electronic databases.

- The library serves as a repository of resources; in other words, it archives, preserves, and keeps track of resources.

- The library serves as a starting point or 'gateway' for locating information for faculty research.

\section{Need of User Empowerment :}

User Empowerment is required in academic library because of following reason:

- It is important to educate the newly admitted students in the beginning of the first year because they don't know the location of the library and have idea how to use library effectively for their curriculum.

- Normally, when students enter in academic institute for studies, they are not capable or poorly motivated to use a library which is seen as a reading room or a place to do homework, but rarely as knowledge and information center or a place where to do research.

- In recent years, major changes in libraries have resulted in the need for expanded skills and abilities, these changes include in implementation of new technologies such as online catalogue, automated circulation system, online database access, online resources etc. users are not aware about various types of resources \& services available in library and also not familiar with various techniques and methods of resource storage and information retrieval by using IT application.

\section{Techniques and Tools of User Empowerment :}

Now a days educating is not limited to the classrooms it's beyond from it. In it, library plays vital role in academic activities and provides core support to teaching, learning, scholarship 
and in research. To keep update, the students, research scholars and faculties with the latest technology trends of new equipment, information products, searching, dissemination, and make them enable to develop self-learning of the usage on authentic information in ethical manner, Library professional can be conduct user empowerment programmes through the following techniques and tools:

\subsection{Techniques:}

$>$ Library can draw formal orientation classes in the library.

$>$ To conduct Lectures or Talks in class-rooms

$>$ Show videos

$>$ Distribution of Library brochures

$>$ Guided library tours

\subsection{Teaching Tools:}

\subsubsection{Information Literacy :}

To empower the users in academic library Information Literacy is one of the most powerful tools. Several kinds of literacy covered in information literacy are here:

- Library literacy:

Users receives information like Library location, various section, organization of collection, Services, Rules and Regulations, Policies

- Computer literacy:

Computer literacy is the ability to familiar with basic knowledge and use of Computer hardware and software, e-mail, Internet

\section{- Media literacy :}

The ability to understand all of the mediums and formats in which information and knowledge are produced, stored, communicated, and accessible,i.e. print books, newspapers, magazines and journals, radio, internet, CD-ROM,DVD, mobile phone, PDF format for text, and JPEG format for photos and graphics.

\section{- Digital literacy :}

To educate about the searching and retrieving of digital resources online databases,

\subsubsection{Current Awareness Service :}



Vyas \& Ms. Daxa Patel/ Page 26-34

Current Awareness Service is essential for students, researchers and all the academic community to keep up-to-date with the most recently published information and developments. Some major current-awareness services arestated below:

* New Books Alerts: The new books alert allows users to browse new library books

* Table of Contents Alerts: The Journal Tables of Contents service (TOCs) allows users to be up-to-date with newly published scholarly information by enabling them to browse, view, save, and search of journal tables of contents .

* Blogs: Blogs started as online personal journals and most effective current awareness tools, because it allows for direct participation and feedback and are often updated frequently.

* RSS Feeds: it stands for Really Simple Syndication) is a format for publishing web content. It's used to push timely information and updates to people.

* Facebook \& Twitter: Facebook \& Twitter are Social networking tools, help the academic users keep up with the daily operations of the Library.

* Citation Alerts : A citation alert notifies users when new publications cite a particular work. Web of Science and ISI's Web of Knowledge provides this service if users create personal profiles.

\section{Role of LIS Professionals in User Empowerment :}

Information Communication \& Technology has restructured every activity of libraries and taken important space in library collection, organization, resources \& services. Now a day's most of the library operations, functions and services are done and provided using ICT. The traditional roles remain but the tools and techniques have changed. Library professionals now use electronics hardware and software to create, collect, communicate, preserve, retrieve and disseminate information. Library professionals are responsible to aware the users with new technologies. Library professionals must have adequate knowledge of ICT skills like library automation, e-resource management, web based library services, institutional repository, webOPAC and organization of information on internet \& intranet. Librarian should become 
proactive to educate the user with efficient and effective use of information through print and electronic media.

Following skills and abilities to be attained by the LIS Professionals and Staff to empowered the users in academic library

$\checkmark$ Ethical Skills

$\checkmark$ Organizational Skills;

$\checkmark$ Managerial Skills;

$\checkmark$ ICT Skills

$\checkmark$ Teaching-Learning Skills

$\checkmark$ Technical Skills;

$\checkmark$ Communication and Human Relations Skills

$\checkmark$ Marketing of Library Products and Services Skills;

Conclusion :Empowering users is essential in digital environment for the effective utilization of library resources and high quality research production and output. The success of any academic library can measure by maximum \&effective utilization of library resources in terms of their research output such as research article, books, patent. Empowered users in academic libraries can empower the institute/organization where they will work and it will help to empower the nation.

\section{Reference :}

1. Kulkarni, Manoj and Deshpande, Neela J. (2012). "Empowering Library Users, Establishing Channel of Communication for Service Quality Expectations of Trainers from Government Administrative Training Institute (ATI) Libraries in India". World Library and Information Congress, $7^{\text {th }}$ IFLA General Conference and Assemly, Helsinki, 2012. Retrieved from:http://conference.ifla.org/past-wlic/2012/203-kulkarni-en.pdf

2. Empowerment.Retrieved from:http://www.businessdictionary.com/definition/empowerment.html\#ixzz3q1VLjSrl

3. Skagen,Therese \&Blaabjerg,Niels Jørgen (2006). "Empowering students through information literacy in the physical and virtual classrooms: Cross-institutional collaboration 
Towards Excellence: An Indexed, Refereed \& Peer Reviewed Journal of Higher Education / Dr. Priyanki Vyas \& Ms. Daxa Patel/ Page 26-34

between library and faculty and between two Scandinavian university libraries". Creating Knowledge IV, Copenhagen, 16-18. August $2006: 1-17$. Retrieved from:

www.ck-iv.dk/.../SkagenBlaabjergTorrasHansen\%20Empowering\%20stu...

4. Ibid. p.1

5. Ibid. p.1

6. Academic

Libraries.

Retrieved

from:http://www.ala.org/news/mediapresscenter/americaslibraries/soal2012/academiclibraries 
Towards Excellence: An Indexed, Refereed \& Peer Reviewed Journal of Higher Education / Dr. Priyanki Vyas \& Ms. Daxa Patel/ Page 26-34

\section{Bibliography}

Chakravarty,Rupak. Information Literacy in the Knowledge Society: Empowering Learners for a Better Tomorrow. Retrieved http://www.researchgate.net/publication/28808532 Information literacy in the knowle dge society empowering learners for a better tomorrow

Current Awarenesshttps://www.library.cornell.edu/research/current-awareness

Fourie,Ina. Empowering users - current awareness on the Internet. The Electronic Library. 17 no.

6. (1999).

Retrieved from:http://www.emeraldinsight.com/doi/pdfplus/10.1108/02640479910329996

Lau, Jesus and Cortes, Jesus.(1997) "Patron Empowerment to use library gateways in LID countries: the case of Maxico". A paper for the User Education Round Table Meeting "Library Gateways IFLA' 97 General Conference, Copenhagen, Denmark; August 29-September 6, 1997.6 Retrieved from: https://core.ac.uk/download/pdf/16292214.pdf

Patel, Rajeshri G. (2015) "Skills for the LIS Professionals in ICT Environment". In proceedings of National Conference on Library Automation: Issued and Remedied in Present Scenario, Edited by Krishna Kant and Ram Chander. Faridabad. Aggarwal College Ballabhgarh. 110-114.

Open Source Technology: Concepts, Methodologies, Tools, and Applications'. Edited by Information Resource Management Association. Retrieved on 30-10-2015. https://books.google.co.in/books?id=OCcdBgAAQBAJ\&pg=PA1789\&lpg=PA1789\&dq=e mpower+the+library+users\&source

Sinha, Manoj Kumar. (2014) Empowering Library and Information Professionals and Library End-Users of Academic Libraries in Changing Environment. Retrieved from:http://www.slideshare.net/mksinha2013/empowering-library-professionals-andend-users-mks. 


\section{Dr. Priyanki Vyas \\ Associate Professor}

Dept. Library and Information Science, School of Humanities \& Social Sciences,

Dr. Babasaheb Ambedkar University, Ahmedabad. (Gujarat)

E-mail : priyankivyas@gmail.com,priyanki.vyas@baou.edu.in $\&$

Ms. Daxa G. Patel

Research Scholar

Library and Information Science

School of Humanities \& Social Sciences,

Dr. Babasaheb Ambedkar University, Ahmedabad. (Gujarat)

E-mail : daxa2407@gmail.com 